\title{
Technology
}

\section{Mars Life Support Systems}

\section{Donald Rapp}

Independent contractor, 1445 Indiana Avenue, South Pasadena, CA 91030, USA, drdrapp@earthlink.net

Citation: Mars 2, 72-82, 2006; doi: 10.1555/mars.2006.0005

History: Submitted: March 17, 2006; Reviewed: May 26, 2006; Accepted: July 1, 2006; Published: September 29, 2006

Editor: Roger D. Bourke, Aerospace Consultant

Reviewers: Anthony R. Gross, National Aeronautics and Space Administration; Robert Zubrin, Pioneer Astronautics.

Open Access: Copyright (c) 2006 Rapp. This is an open-access paper distributed under the terms of a Creative Commons Attribution License, which permits unrestricted use, distribution, and reproduction in any medium, provided the original work is properly cited.

\begin{abstract}
Background: A critical element of planning human missions to Mars involves life support systems. The requirements for air, food, water and waste disposal materials in human missions to Mars total well over 100 metric tons and possibly as much as 200 metric tons. Translated back into an equivalent mass required in low Earth orbit, this figure would increase by at least a factor of seven, depending on mission architecture, requiring at least half a dozen heavy-lift launches solely for life support, and thus driving the cost and complexity of human missions to Mars beyond any reasonable limit. Recycling and possibly in situ utilization of indigenous Mars water resources are therefore critical enabling capabilities for human missions to Mars. Previous "design reference missions" assumed that high-performance life support systems would function flawlessly for the $\sim 2.7$ year round trip to Mars. However, life support systems developed for the International Space Station do not appear to have the longevity and reliability needed for Mars. As NASA moves forward with the current human exploration initiative, we need some means of estimating the required mass of life support system that goes beyond wild optimistic guesses. NASA's Advanced Life Support (ALS) project has been advancing the technology of recycling of water and air resources in human space missions for some time. Emphasis has been placed on recovery percentage and trace contaminant removal.
\end{abstract}

Method: Mass estimates for physical plant and back-up caches are provided by NASA. A critical review was carried out based on NASA reports dealing with life support systems and these were judged in the context of "design reference missions" for humans making the round trip to Mars.

Conclusion: ALS estimates of masses of life support systems are based on research and analysis, but the sources of reported performance data are not traceable to experimental data, and the reliability and lifetime of these systems is very uncertain. These estimates are optimistic, and when translated into engineering systems requiring margins, spares and fail-safe performance, are likely to increase significantly. Nevertheless, even these optimistic estimates require a significant initial mass in low Earth orbit, estimated as 210 metric tons. Life support remains at best, a significant mass, cost and risk factor for human missions to Mars, and at worst a major show stopper.

\section{Introduction}

The NASA Exploration Systems Architecture Study (ESAS) Final Report (Anonymous 2005) briefly outlines a design reference mission (DRM) for human exploration of Mars. This DRM concept is based to some extent on the DRM previously developed by NASA Johnson Space Center (JSC) known as "DRM-3" (Drake 1998) that was a modification of a previous NASA-JSC DRM known as "DRM-1" (Hoffman and Kaplan 1997). This was followed by the so-called "DualLanders" DRM, but the ESAS has indicated that it is relying on DRM-3. In addition, independent Mars DRMs were developed by Robert Zubrin ("Mars Direct") and the Mars Society led by James Burke.

Life support during the three major legs of the mission (transit to Mars, surface stay, and return to Earth) poses major challenges for human missions to Mars. The estimated requirements for consumables for a crew of six for round trip to the surface of Mars exceeds 100 metric tons (mT) and may be as much as $\sim 200 \mathrm{mT}$. This would require roughly 6 to 12 launches with a heavy-lift launch vehicle $(125 \mathrm{mT}$ to low Earth orbit (LEO)) just to provide life support if neither recycling nor use of indigenous water from Mars were used. 
Clearly, life support is critical for human missions to Mars, and recycling and possibly use of indigenous Mars water resources are necessary elements of any rational plan to make such missions feasible and affordable. Unfortunately, none of the DRMs dealt with life support in any detail and it is impossible to derive reliable estimates of life support masses from these studies. Therefore it is appropriate to review the available data on life support with the goal of providing more reliable estimates of required life support masses for human missions to Mars to support future DRM development.

Life support, as defined by the NASA Advanced Life Support Project (ALS), includes the following elements:

- Air

- Biomass

- Food

- Thermal

- Waste

- Water

Each of these elements interacts in a comprehensive overall system that maximizes recycling of waste products. These systems are complex and highly interactive.

Not only must the life support system (LSS) provide the gross requirements for these elements, but it must also monitor trace contaminants and remove them to an acceptable level. It is also worth noting that reduction/ elimination of pollutants from air and water, even trace amounts of some pollutants, occupies a great deal of attention in various ALS reports, whereas the simple macroscopic mass balances do not get as much attention. Obviously, pollutant control is a vital part of an ECLSS (environmental control and life support system), but ultimately, resources must be supplied, a physical plant is required, and a back-up cache is needed, and these masses must be estimated in order to plan a mission. Extracting such data from ALS reports is not always straightforward. However, from the ALS point of view, the simple macroscopic mass balances (and to some extent the energy balances as well) are well understood by the System Integration, Modeling and Analysis (SIMA) element within NASA and they are implemented in software tools such as the MS Excel-based Advanced Life Support Sizing Analysis Tool (ALSSAT). In other words, mass balances are regarded as a solved problem by the ALS. Nevertheless, the overall mass requirements of the life support system defines the scope of the problem and ought to be summarized in each progress report.

Most of the available reports provide system estimates of masses for the various elements of the LSS. The basic element masses are listed, as well as "equivalent system masses" (ESM) that include additional mass to account for the required power system, thermal system and human oversight requirements associated with operation of the LSS. There are a number of reports, but these tend to be overlapping, and in some cases they are yearly updates of previous versions. As is typical at JSC, the actual work on LSS is contracted out. Most of the LSS reports were edited by Dr. Anthony J. Hanford. Dr. Hanford does a good job of reporting the ALS estimates of LSS masses although the actual experimental basis for the reported numbers remains unclear. ALS is working on this problem.

The ALS data are reported in two segments. One segment is claimed to be "state of art" based on "the International Space Station (ISS) Upgrade Mission" and the other segment is for an "Advanced Life Support" system that is based on advanced technologies currently under development within NASA. It is claimed that only technologies at NASA TRL 5 or greater are included in the assessments. The ALS reports provide the reader with sets of numbers. However, the connection between the baseline data in the reports and actual experience with the ISS is very difficult to discern. It is not clear how much experimental data underlie the tables, and how much data are estimated from modeling. Nor is it clear whether these systems are reliable for the long transits and surface stays of Mars missions.

A recent report (Sanders and Duke 2005) indicates that: "Experience with Mir, International Space Station (ISS), and Shuttle, have shown that even with extensive ground checkout, hardware failures occur. For long duration missions, such as Mir and ISS, orbital replacement units (ORUs) must be stored on-orbit or delivered from Earth to maintain operations, even with systems that were initially two-fault tolerant. Long surface stays on the Moon and Mars will require a different method of failure recovery than ORU's." This might add to the required back-up cache and/or require some spares or redundant units that would double (or more) the mass of the system. Obviously, longterm testing is needed here. Sanders and Duke (2005) emphasize the need for ISRU as a back-up for a Environmental Control and Life Support System (ECLSS), pointing out the unreliability of ECLSS. It is also interesting that the ALS appears to be rather cautious regarding the potential for widespread indigenous Mars water resources to impact life support on Mars, despite the fact that this impact could potentially be a major benefit in mass reduction and safety. Admittedly, acquisition of such water resources will require sophisticated machinery and there are concerns regarding planetary protection. Nevertheless, this aspect would seem to deserve more attention in ALS activities.

ALS has provided tables of data on estimated masses for LSS, but without a strong connection to experimental data and validation, these data are of uncertain validity. There is an Advanced Life Support Project with participating NASA field centers, Ames Research Center, Kennedy Space Center, Marshal Space Flight Center and the JSC serving as the lead center. This project is supposed to carry out simulation tests of closed LSS with humans in chambers. However, documentation of this project is lacking. In fact, no experimental data are available, although the usual extensive set of goals and objectives are well documented (Anonymous 2002). 
It is difficult to judge the veracity of the data presented by ALS. In the present paper, primary emphasis is placed on "state of the art" technologies, but even these lack a direct connection to experimental performance data, and data on reliability and lifetime are unavailable.

A set of tenets for engineering of life support systems is provided by Graf et al. (2002). However, these tenets apply more directly to flight hardware systems than they do to advanced technology. It is noteworthy that all of the mass estimates provided by the ALS are from the research arm of NASA, and they do not include allowances for margins, redundancy or spares. Furthermore there is essentially no discussion of lifetimes and longevity of systems in these reports.

\section{Fundamental Requirements}

Fundamental design values are presented by Hanford (2004B). These values represent the current best estimates for various parameters based on an assemblage of data, analysis and experience. All subsequent reports are based on the values provided by Hanford (2004B). This report is the ALS Baseline Values and Assumptions Document (BVAD) that is aimed at providing analysts and modelers with a common set of initial values and assumptions, i.e., a baseline. The BVAD identifies specific physical quantities that define life support systems from an analysis and modeling perspective. For each physical quantity so identified, the BVAD provides a nominal or baseline value plus a range of possible or observed values. Finally, the BVAD claims to "document each entry with a description of the quantity's use, value selection rationale, and appropriate references." Unfortunately, it is difficult to determine the underlying basis of specific numbers presented in this report, as to what is based on experiment, what is estimated by analysis, and how well these figures apply to a system that is reliable for a lengthy Mars excursion. Nevertheless, the following requirements are based, at least partly on this report.

\section{Oxygen Requirements}

Hanford (2004B) provides data for oxygen consumed (kg/CM-day) as ranging from 0.385 (minimum) to 0.835 (nominal) to 1.852 (maximum). The origin of these numbers is not completely clear. No data seem to be given on requirements for buffer gas. Lange et al. (2003) provides the data shown in Table 1A.

\section{Water Requirements}

For short-duration lunar missions of 30 days or less, they indicate a water usage rate in $\mathrm{kg} / \mathrm{CM}$-day ranging from 2.9 (minimum) to 4.5 (nominal) to 7.7 (maximum). The basis for these figures is cited as a "personal communication from Ewert and Drake in 2000."

Water usage on planetary bases are provided in Table 1B. The figures in Table $1 \mathrm{~B}$ for a long-term base are in a range that seem to be widely used. Note, however, that a shower is allocated $5.4 \mathrm{~kg}$ and this equals 5.4 liters, which is a rather quick sparse shower.

Table 1A. Oxygen requirements. (Lange et al. 2003)

\begin{tabular}{cc}
\hline Category & $\begin{array}{c}\text { Oxygen Requirements: } \\
{[\mathrm{kg} /(\mathrm{CM}-\text { day })]}\end{array}$ \\
\hline Low Activity Metabolic Load & 0.78 \\
Nominal Activity Metabolic Load & 0.84 \\
High Activity Metabolic Load & 0.96 \\
5th Percentile Nominal Female & 0.52 \\
95th Percentile Nominal Male & 1.11 \\
\hline
\end{tabular}

Table 1B. Water requirements ( $\mathrm{kg} / \mathrm{CM}$-day). (Hanford 2004B)

\begin{tabular}{ccc}
\hline Water Need & $\begin{array}{c}\text { Short Term } \\
\text { Landed } \\
\text { Base }\end{array}$ & $\begin{array}{c}\text { Long Term } \\
\text { Landed } \\
\text { Base }\end{array}$ \\
\hline Crew Drinks & 2.00 & 2.00 \\
Shower (one per two days) & 2.72 & 2.72 \\
Urinal Flush & 0.50 & 0.50 \\
Oral Hygiene & 0.37 & 0.37 \\
Hand Wash & 4.08 & 4.08 \\
Laundry & $\mathrm{n} / \mathrm{a}$ & 12.47 \\
Dish Wash & $\mathrm{n} / \mathrm{a}$ & 5.44 \\
Food Processing and Preparation & $\mathrm{TBD}$ & $\mathrm{TBD}$ \\
Total Hygiene Consumption & 7.67 & 25.58 \\
Metabolic and related consumption & 2.0 & 2.0 \\
Total Water Consumption & 9.67 & 27.58 \\
\hline
\end{tabular}

* To be determined. (Hanford 2004B)

\section{Waste Disposal Requirements}

Wastes include crew metabolic wastes, food packaging, wasted food, paper, tape, soiled clothing, brines, inedible biomass, expended hygiene supplies, and equipment replacement parts from the other subsystems. Current NASA spacecraft waste-handling approaches essentially rely on dumping or storage of wastes.

Hanford (2004B) refers to historical waste data from Skylab and the Shuttle. For longer-term Mars missions, this report states:

"Waste treatment and removal for missions to Mars and other likely near-term destinations will be more challenging due to the longer mission duration regardless of complications from the environment. Waste management for such missions may employ more efficient versions of technologies developed for Shuttle and ISS, or completely different approaches may be more cost effective. Future missions may also generate significant amounts of inedible biomass. In later or far-term missions, inedible biomass may dominate all other trash sources.... Though unavailable here, waste volumes can be significant.... Because many spacecraft [ECLSS] systems routinely replace parts [e.g. filters] during scheduled maintenance on long-duration missions, a comprehensive list of wastes is contingent upon the hardware and configurations used throughout the vehicle.... The degree of confidence in data values is highly variable and often unknown. In some cases, data have not been diligently 
collected, and mass estimates are included. In other cases, the values are contingent upon environmental variables...."

Solid waste management for future long-duration missions requires consideration of:

- Feces

- Urine

- Menstruation

- Paper

- Miscellaneous Body Wastes

- Consumable Hygiene Products

- Food Packaging, Inedible Biomass, and Wasted Food

- Paper, Tape, Hygiene Products, and Clothing

- Grey water and Brine

- Other Waste Streams

While Hanford (2004B) provides estimates of these waste streams, it is not clear how much material must be brought on board specifically for collection and storage of waste materials. The discussion of waste treatment is difficult to comprehend. According to ALS, waste disposal on longduration missions is still under study. Table 1C provides a very crude estimate.

\section{Summary of Requirements}

As Table 1C shows, subsequent reports utilized the same values as given in Hanford (2004B), although it is not clear why Hanford (2004A) and Hanford (2005) left out dishwashing water. In addition, Lange et al. (2003) provide additional details on oxygen requirements (Table $1 \mathrm{~A}$ ). The far right column of Table 1B was derived by averaging several unpublished reports, compendia and textbook recommendations.

\section{Characterizing LSS for a Human Mission to Mars}

In order to characterize LSS for a human mission to Mars, a first step would be to catalog the inventory of consumables that are needed for each leg of the trip to support a crew of six, assuming no ECLSS. One should tabulate how much food, water (various qualities), oxygen, nitrogen and waste disposal materials are needed, first on a per-crew-memberper-day basis, and then for the whole stay for a crew of 6 . This basic information is not presented in any of the ALS reports.

The mass of the physical plant needed to supply the consumables for each leg of the trip must be estimated for each ECLSS system under consideration, as well as the recovery percentages for the air and water systems. From the recovery percentage, one can calculate the size of the backup cache needed for replenishment of lost resources during recycling. Then, for each of the air and water systems, five quantities would be reported:
Table 1C. Fundamental Requirements for Mars Surface Habitat (kg/CM-day).

\begin{tabular}{|c|c|c|c|c|}
\hline & $\underline{\text { Hanford }}$ & $\frac{\text { Hanford }}{(2005)}$ & $\frac{\text { Hanford }}{(2004 \mathrm{~B})}$ & $\begin{array}{l}\text { This } \\
\text { paper }\end{array}$ \\
\hline $\begin{array}{c}\text { Oral Hygiene } \\
\text { Water }\end{array}$ & 0.363 & 0.363 & 0.37 & \\
\hline $\begin{array}{c}\text { Hand / Face Wash } \\
\text { Water }\end{array}$ & 4.082 & 4.082 & 4.1 & \\
\hline Urinal Flush Water & 0.494 & 0.494 & 0.5 & \\
\hline Laundry Water & 12.474 & 12.474 & 12.5 & \\
\hline Shower Water & 2.722 & 2.722 & 2.7 & \\
\hline Dishwashing Water & 0 & 0 & 5.4 & \\
\hline Drinking Water & 2.000 & 2.000 & 2.0 & \\
\hline TOTAL WATER & 22.1 & 22.1 & 27.6 & $30.0(a)$ \\
\hline OXYGEN & & & $0.84(b)$ & 1.0 \\
\hline $\begin{array}{l}\text { BUFFER GAS } \\
\text { (N2?) }\end{array}$ & & & $2.1(c)$ & 3.0 \\
\hline FOOD & & & (d) & 1.5 \\
\hline $\begin{array}{c}\text { WASTE } \\
\text { DI SPOSAL MTLS }\end{array}$ & & & & 0.5 \\
\hline
\end{tabular}

(a) Potable $=4$ and wash $=26$, (b) Range depends on metabolic rate, varies from 0.39 to 1.85 , (c) Buffer gas requirement was not specified. However, cabin pressure and oxygen partial pressure were specified and based on that, I estimated the buffer gas requirement. Buffer gas requirements depend on the vehicle leakage rate, both through seams and from airlock operations. (d) The discussion of food was extensive, tedious and confusing and it was difficult to extract a specific requirement.

1) The total mass of the resource needed for crew of six over the number of days required for the leg of the trip (MT).

2) The mass of the physical plant (MPP)

3) The recovery percentage $(R P)$

4) The mass of the back-up cache for replenishment: $M B=(100-R P) M T / 100$

5) Total mass of the LSS that supplies MT of resource: $M L S=M P P+M B$

A useful figure of merit is the ratio $M L S$ / MT that specifies the total mass of the system per unit mass of resource supplied.

In addition to these performance estimates, the reliability and longevity of such systems should be discussed, and additional mass provided for margins, spares, and redundancy, as needed.

Finally, the potential impact of utilizing indigenous water on Mars for surface systems should be considered and incorporated into plans as appropriate.

\section{ALS Estimates of LSS Mass for Mars Missions}

\section{Introduction}

Hanford (2005) presents a considerable amount of relevant data but the source of the data is not indicated. Hanford's data are separated into two groups, one for "state of art" based on "the ISS Upgrade Mission" and the other for an "Advanced 
Table 2. Total Mass of ECLSS System for Mars Transit Vehicle using Baseline ECLSS Technologies. ESM is equivalent system mass including estimates of mass for power system, cooling and crew time. (360-day duration - crew of six) (Hanford 2005)

\begin{tabular}{ccccccc}
\hline $\begin{array}{c}\text { Subsystem / } \\
\text { Interface }\end{array}$ & $\begin{array}{c}\mathrm{M} \\
\mathrm{kg}\end{array}$ & $\begin{array}{c}\mathrm{V} \\
\mathrm{m}^{3}\end{array}$ & $\begin{array}{c}\mathrm{P} \\
\mathrm{kWe}\end{array}$ & $\begin{array}{c}\mathrm{C} \\
\mathrm{kWth}\end{array}$ & $\begin{array}{c}\mathrm{CT} \\
\mathrm{CM}-\mathrm{hr}\end{array}$ & $\begin{array}{c}\mathrm{ESM} \\
\mathrm{kg}\end{array}$ \\
\hline Air & 2190 & 3.3 & 4.2 & 2.7 & 12.8 & 3334 \\
Biomass & 761 & 17.0 & 6.1 & 6.1 & 0.0 & 2607 \\
Food & 2840 & 13.1 & 1.9 & 1.9 & 0.0 & 3475 \\
Thermal & 329 & 1.0 & 0.9 & 0.9 & 2.0 & 586 \\
Waste & 382 & 9.7 & 0.0 & 0.0 & 0.0 & 475 \\
$\quad$ Water & 3353 & 5.5 & 1.1 & 1.1 & 0.0 & 3715 \\
$\begin{array}{c}\text { Extravehicular } \\
\text { Activity Support } \\
\text { Human }\end{array}$ & 0 & 0.0 & 0.0 & 0.0 & 0.0 & 0 \\
$\begin{array}{c}\text { Accommodations } \\
\text { Totals }\end{array}$ & 1763 & 6.9 & 0.0 & 0.0 & 0.0 & 1826 \\
\hline
\end{tabular}

$\mathrm{M}=$ mass, $\mathrm{V}=$ volume, $\mathrm{P}=$ power, $\mathrm{kWe}=$ kilowatts-electric, $\mathrm{C}$ = cooling, $\mathrm{kWth}=$ kilowatts-thermal, $\mathrm{CT}=$ crew time and ESM $=$ equivalent system mass.

Life Support" system. In the present paper, only "state of art" data are utilized.

Hanford (2004A) appears to be an earlier version of Hanford (2005) but it is interesting that Hanford (2004A) provides recovery percentages whereas Hanford (2005) merely indicates that recovery is high. For each of the three Mars

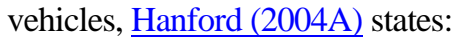

"Urine is processed by vapor compression distillation. Eighty-eight percent water recovery is claimed. The brine is dumped or placed in waste storage. All grey water, including hygiene water, effluent from the vapor compression distillation, and condensate from dehumidification, is processed through a water processor. The water processor employs two multifiltration units, a volatile removal assembly, phase separators, and an ion exchange bed. A process control water quality monitor provides water quality assurance. Efficiency of recovery is high, but many expendables, mostly filter cartridges, are needed."

Hanford (2005) also provides the following caveats:

"This type of analysis includes several inescapable sources of variation from actual flight systems. (1) These estimations fail to consider contingency or redundancy in any detail. (2) All calculations above use only single-string life support system architecture. (3) The preliminary nature of the data employed for the advanced equipment."

\section{LSS Data for Mars Missions}

The results of Hanford (2005) for a (two-way) Mars Transit Vehicle, a Mars Ascent/ Descent Lander, and a Mars Surface Habitat Lander for a crew of six are summarized in Tables 2, 3 and 4 , respectively.
The masses provided in Tables 2, 3 and 4 are total, including both the ECLSS and a back-up cache to account for the fact that recovery is not $100 \%$. To distinguish between the physical plant and storage, additional detailed data are required, and this is shown for the Mars Transit Vehicle in Tables 5 and 6. Similar data were available for the other vehicles. Note that in Tables 5 and 6, that Hanford (2005) did not distinguish between the mass of the storage tank and the mass of the resource stored within the tank. Therefore it is difficult to infer the mass of the back-up cache in these systems.

An overall comparison of data from Hanford (2005) and Hanford (2004C), including a breakdown of masses for storage vs. physical plant is provided in Table 7. The ALS does not calculate the total amount of resource that would be required if there were no recycling. Therefore the data in the requirements column were estimated herein. Table 7 shows that ALS has continued to refine their models, with the trend being downward. Table 7 also indicates that the estimated mass of the air and water systems are far lower than the total amounts of these resources consumed, implying a high recovery rate.

\section{Implied Recovery Efficiencies}

Because Hanford (2005) does not provide the overall requirement that needs to be satisfied, it is not clear from his tables what recovery percentages are implied. Therefore, Table 8, 9 and 10 were prepared herein as companions to Tables 2, 3, and 4, respectively, using estimated values for the total requirement. The 2 nd columns of Tables 8,9 and 10 present the mass data for the physical plant from Hanford (2005). The 3rd columns present the masses allocated by Hanford (2005) to water or air storage. It is not clear what fraction of these values represents water and air, and what fraction represents tankage mass. If we assume that these quantities are all air and water (defined as $M B$ ) and neglect tankage mass, we can calculate a lower limit to the recovery percentage:

$$
R P=100(M T-M B) / M T
$$

where $M T$ the total amount of resource required and is provided in columns 4 of Tables 8, 9 and 10 from estimates made herein (the lower values in the ranges were used). The recovery percentages are given in column 5 of these tables.

For air and water, the results for recycle percentages and ratios of ECLSS system mass to required resource mass are summarized in Table 11. For the Mars Ascent/Descent Lander, the required ECLSS air system seems to be much heavier than the required air mass. This may be due to the heavy mass of tankage and limited recycling on this vehicle but it is still difficult to understand. In general. the mass of the air supply system is a much higher percentage of the required resource mass than the comparable ratio for the water system.

\section{Trade Analysis}


Table 3. Total Mass of ECLSS System for Mars Ascent/Descent Lander using Baseline ECLSS Technologies. ESM is equivalent system mass including estimates of mass for power system, cooling and crew time. (30-day duration - crew of six) (Hanford 2005)

\begin{tabular}{ccccccc}
\hline $\begin{array}{c}\text { Subsystem / } \\
\text { Interface }\end{array}$ & $\begin{array}{c}\mathrm{M} \\
\mathrm{kg}\end{array}$ & $\begin{array}{c}\mathrm{V} \\
\mathrm{m}^{3}\end{array}$ & $\begin{array}{c}\mathrm{P} \\
\mathrm{kWe}\end{array}$ & $\begin{array}{c}\mathrm{C} \\
\mathrm{kWth}\end{array}$ & $\begin{array}{c}\mathrm{CT} \\
\mathrm{CM}-\mathrm{hr}\end{array}$ & $\begin{array}{c}\mathrm{ESM} \\
\mathrm{kg}\end{array}$ \\
\hline Air & 1071 & 2.16 & 4.251 & 2.742 & 1.07 & 2586 \\
Biomass & 0 & 0.00 & 0.000 & 0.000 & 0.00 & 0 \\
Food & 620 & 3.37 & 2.128 & 2.128 & 0.00 & 1638 \\
Thermal & 296 & 0.92 & 0.822 & 0.822 & 0.17 & 665 \\
Waste & 69 & 1.02 & 0.014 & 0.014 & 0.00 & 142 \\
$\quad$ Water & 737 & 2.88 & 0.896 & 0.896 & 0.00 & 1263 \\
$\begin{array}{c}\text { Extravehicular } \\
\text { Activity Support } \\
\text { Human }\end{array}$ & 22 & 0.25 & 0.000 & 0.000 & 0.00 & 38 \\
$\begin{array}{c}\text { Accommodations } \\
\text { Totals }\end{array}$ & 188 & 0.65 & 0.000 & 0.000 & 0.00 & 231 \\
& 3001 & 11.25 & 8.111 & 6.602 & 1.24 & 6560
\end{tabular}

$\mathrm{M}=$ mass, $\mathrm{V}=$ volume, $\mathrm{P}=$ power, $\mathrm{kWe}=$ kilowatts-electric, $\mathrm{C}$ = cooling, $\mathrm{kWth}=$ kilowatts-thermal, $\mathrm{CT}=$ crew time and ESM $=$ equivalent system mass.

Table 4. Total Mass of ECLSS System for Mars Surface Habitat Lander using Baseline ECLSS Technologies. ESM is equivalent system mass including estimates of mass for power system, cooling and crew time. (600-day duration - crew of six) (Hanford 2005)

\begin{tabular}{|c|c|c|c|c|c|c|}
\hline $\begin{array}{l}\text { Subsystem / } \\
\text { Interface }\end{array}$ & $\begin{array}{l}M \\
\mathrm{~kg}\end{array}$ & $\begin{array}{c}V \\
m^{3}\end{array}$ & $\begin{array}{c}P \\
k W e\end{array}$ & $\begin{array}{c}\mathrm{C} \\
\mathrm{kWth}\end{array}$ & $\begin{array}{c}\text { CT } \\
\text { CM-hr }\end{array}$ & $\begin{array}{c}\mathrm{ESM} \\
\mathrm{kg}\end{array}$ \\
\hline Air & 4195 & 5.52 & 5.847 & 3.732 & 21.30 & 5315 \\
\hline Biomass & 898 & 17.03 & 6.099 & 6.099 & 0.00 & 2469 \\
\hline Food & 7580 & 38.39 & 4.272 & 4.272 & 0.00 & 8923 \\
\hline Thermal & 382 & 1.17 & 1.032 & 1.032 & 3.33 & 636 \\
\hline Waste & 668 & 17.66 & 0.014 & 0.014 & 0.00 & 833 \\
\hline Water & 10380 & 9.82 & 1.285 & 1.285 & 0.00 & 10768 \\
\hline $\begin{array}{l}\text { Extravehicular } \\
\text { Activity Support }\end{array}$ & 1292 & 2.91 & 2.500 & 2.500 & 0.00 & 1899 \\
\hline $\begin{array}{c}\text { Human } \\
\text { Accommodations }\end{array}$ & 2938 & 11.45 & 0.000 & 0.000 & 0.00 & 3043 \\
\hline Totals & 28333 & 103.95 & 21.048 & 18.934 & 24.63 & 33900 \\
\hline
\end{tabular}

Anderson (2004) carried out system trade comparisons of alternative water recovery systems. It is claimed that the baseline ISS water recovery system "achieves approximately 95\% total recovery." This reference compared the "Integrated Water Recovery System" (IWRS) and the "Vapor Phase Catalytic Ammonia Removal System" (VPCAR) with the baseline. The IWRS and VPCAR system are claimed to achieve $98 \%$ water recovery.

After a mass estimate for a system was prepared, it was multiplied by a factor to account for the mass due to components such as lines, packaging or acoustic enclosures, brackets, bolts, and other miscellaneous hardware used to install the ECLSS system into a vehicle. Based on limited data, they used a factor 1.6 for the IWRS and 1.4 for the
VPCAR.

For the 360-day Mars transit mission it was estimated that wastewater production from a crew of six is $29 \mathrm{~kg} /$ day. Wastewater was included from urine, flush water, condensate, and water recovered from $\mathrm{CO}_{2}$ reduction in a Sabatier reaction. For a 500-day surface habitat with crew of six, it was estimated that the total wastewater load was 77 $\mathrm{kg} /$ day. This included wastewaters from urine, flush-water, oral hygiene, hand-wash and face-wash, shower, as well as condensate water and water recovered from a Sabatier reaction. Apparently, it was assumed that for the two 180day transfers to and from Mars, there would be no oral hygiene, hand-wash, face-wash, or showers, which may not be realistic. Our estimate for a crew of six for either vehicle is $6 \times 30=180 \mathrm{~kg} /$ day. Hanford (2005) would have estimated about $132 \mathrm{~kg} /$ day and Hanford (2004B) would have estimated about $166 \mathrm{~kg} /$ day. The figures given by Anderson (2004) appear to be unusually low.

The equivalent system masses estimated by Anderson (2004) for water processing units are in the range around $1800 \mathrm{~kg}$ for Mars transit and $4500 \mathrm{~kg}$ for the surface habitat, using IWRS or the baseline ISS system. With the VPCAR, these masses drop roughly in half. These estimates are considerably more optimistic than those of Hanford (2005).

\section{Requirements Document}

Lange et al. (2003) specifies that hygienic water amounts to $2.84 \mathrm{~kg} /$ person per day. This reference provides more details in regard to air, and their data are reproduced here as Table 1C.

\section{Advanced Life Support Project}

ALS has embarked on a program to acquire relevant data via the Advanced Life Support Project.

The Lunar-Mars Life Support Test Project (LMLSTP) consisted of a series of closed-chamber, human tests that demonstrated operation of closed-loop life support systems for increasingly longer durations. The final test in the series, the Phase III test, incorporated the use of biological systems as well as physicochemical (P/C) life support system technologies to continuously recycle air, water, and part of the solid waste stream generated by a four-person crew for 91 days (Anonymous 2002).

According to this report, the Phase III test was conducted using two environmental test chambers at the National Aeronautics and Space Administration's (NASA) Johnson Space Center (JSC). The Integrated Life Support Systems Test Facility (ILSSTF) housed the crew as well as most of the life support systems. This chamber was integrated with the Variable Pressure Growth Chamber (VPGC) in which wheat was grown to provide supplemental food and air revitalization for the crew during the test. The human portion of the test began on September 19, 1997, and ended on December 19, 1997, with a duration of 91 days. The wheat crop was initially planted on July 23, 1997, and the final 
Table 5. Mass breakdown $(\mathrm{kg})$ for air system in Mars Transit Vehicle. (Hanford 2005)

\begin{tabular}{lr}
\hline Air Subsystem & $\mathbf{2 1 9 0 . 1 0}$ \\
\hline Atmospheric Control System & \\
Atmospheric Pressure Control & 119.40 \\
Atmosphere Revitalization System & \\
Carbon Dioxide Removal & 179.12 \\
Carbon Dioxide Reduction & 0.00 \\
Oxygen Generation & 379.16 \\
Gaseous Trace Contaminant Control & 85.81 \\
Atmosphere Composition Monitoring Assembly & 54.30 \\
Sample Delivery System & 35.11 \\
Airlock Carbon Dioxide Removal & 0.00 \\
Gas Storage & \\
Nitrogen Storage & $1,028.73$ \\
Oxygen Storage & 300.17 \\
Fire Detection and Suppression & \\
Fire Detection System & 1.50 \\
Fire Suppression System & 6.80 \\
\hline
\end{tabular}

Table 6. Mass breakdown $(\mathrm{kg})$ for water system in Mars Transit Vehicle. (Hanford 2005)

\begin{tabular}{lr}
\hline Water Subsystem & $\mathbf{3 3 5 3 . 0 3}$ \\
\hline Urine / Waste water Collection System & $\mathbf{4 . 5 5}$ \\
Water Recovery System & \\
Water Treatment Process & $2,463.74$ \\
Urine, Hygiene \& Potable Water, \& Brine & 181.57 \\
Storage Tankage & 5.72 \\
Microbial Check Valve & 36.11 \\
Process Controller & 14.07 \\
Water Quality Monitoring & 51.73 \\
Product Water Delivery System & \\
Water Storage & 0.00 \\
Hygiene Water Storage & 595.54 \\
Potable Water Storage & 0.00 \\
Urine Storage & 0.00 \\
Waste water Storage &
\end{tabular}

harvest was on January 9, 1998.

The Phase III test was the first test conducted by NASA integrating human test subjects with biological and P/C life support systems. This integration was accomplished in four distinct ways. First, the $\mathrm{CO}_{2}$ generated by the crew in the ILSSTF was separated from the atmosphere, concentrated, and used by wheat in the VPGC as the major source of $\mathrm{CO}_{2}$ for photosynthesis. In tandem with this process, $95 \%$ of the $\mathrm{O}_{2}$ produced by the wheat plants was separated, concentrated, and used by the crew during respiration. On average, the plants consumed $\mathrm{CO}_{2}$ and generated $\mathrm{O}_{2}$ equal to that required by one crew person over the course of the test. The remaining three person-equivalent's worth of $\mathrm{CO}_{2}$ removal and reduction and $\mathrm{O}_{2}$ production was accomplished with $\mathrm{P} / \mathrm{C}$ systems.

The second biological and P/C integration involved the Water Recovery System (WRS). The WRS processed 111 $\mathrm{kg}$ of waste water each day, equivalent to the daily requirement for a crew of four. Bioreactors were used as the primary treatment step for the combined waste water stream generated by the crew's showering, hand washing, clothes washing, and urination as well as humidity condensate from the chamber. These bioreactors depended on microbial species to oxidize organic carbonaceous and nitrogenous materials in the waste water. These bioreactors were integrated with $\mathrm{P} / \mathrm{C}$ subsystems, which removed inorganic salts and performed final polishing of the water before being reused by the crew. The initial 8-day supply of water cycled though the chamber and the crew 10 times. No additional water was required during the test.

The third biological and P/C integration method pertained to the Solid Waste Incineration System (SWIS) and the wheat plants. The crew's fecal material was incinerated in a fluidized bed incinerator. Oxygen required for the combustion of the fecal material was provided from the $\mathrm{O}_{2}$ produced by the wheat plants. The $\mathrm{CO}_{2}$ produced as a result of the incineration reaction was used as a second source of $\mathrm{CO}_{2}$ for wheat photosynthesis. The test utilized a hierarchical control system for handling the competition for resources. This competition is inevitable when biological systems, which operate continuously, are used to provide the life support function for a crew. Wheat was harvested periodically throughout the test and after drying, threshing, and milling, the wheat flour was provided to the crew to bake bread in the ILSSTF. The wheat provided less than $5 \%$ of the crew's caloric intake during the course of the test.

The final biological and P/C integration method was the incorporation of a small chamber to grow lettuce within the ILSSTF. This chamber was able to provide 4 heads of lettuce for the crew approximately every 11 days.

The test was claimed to be very successful in integrating biological and P/C life support system technologies for longduration life support. The use of a biologically based WRS demonstrated the operation of a system that recovered essentially $100 \%$ of the influent waste water for reuse. In addition, the first step in recovering useful materials from the crew's fecal material was demonstrated in an integrated system. Future testing would be aimed at developing these capabilities to bring about closure of the food and waste loops using regenerative life support technologies.

These tests appear to have been a good start, but only a first step toward proving that an ECLSS for Mars is feasible. In 2002, this work seems to have evolved into another program called the Advanced Life Support Project. A Plan for this project is available on the ALS web site (Anonymous 2002). The plan seems very ambitious. However it is not clear how much progress was made since the plan was published 4 years ago.

\section{Required Mass in Low Earth Orbit}

In planning design reference missions, an important consideration is the required initial mass in low Earth orbit (IMLEO). The required IMLEO for any mass that must be used in transit to Mars, on the surface of Mars, or in return from Mars can be estimated from the mission architecture using the rocket equation for propulsion steps, and taking into account aero-entry where appropriate. A simple 
Table 7. ALS estimates of system and storage masses for Mars human missions.

\begin{tabular}{|c|c|c|c|c|c|c|}
\hline & \multirow{2}{*}{ Resource } & \multirow{2}{*}{$\begin{array}{l}\text { Requirement } \\
(\mathrm{kg})\end{array}$} & \multicolumn{2}{|c|}{ Hanford (2005) } & \multicolumn{2}{|c|}{ Hanford (2004C) } \\
\hline & & & System & Storage & System & Storage \\
\hline \multirow[b]{2}{*}{ Mars Transit Vehicle } & air & $6500-8700$ & 864.5 & 1328.9 & 876.1 & 1339.9 \\
\hline & water & $\begin{array}{c}47,500- \\
65,000 \\
\end{array}$ & 2762.5 & 596.0 & 1980.6 & 606.7 \\
\hline \multirow{2}{*}{$\begin{array}{c}\text { Mars Ascent/ Descent } \\
\text { Lander }\end{array}$} & air & $540-720$ & 809.5 & 263.3 & 859.9 & 270.1 \\
\hline & water & $4000-5400$ & 648.8 & 90.8 & 645.8 & 96.2 \\
\hline \multirow{2}{*}{ Mars Surface Habitat } & air & $\begin{array}{c}10,800- \\
14,400\end{array}$ & 1270.9 & 2929.2 & 980.8 & 2942.4 \\
\hline & water & $\begin{array}{l}79,200- \\
108,000\end{array}$ & 4142.3 & 6248 & 2906.9 & 6247.1 \\
\hline
\end{tabular}

calculation based on use of $\mathrm{H}_{2}-\mathrm{O}_{2}$ propulsion for Earth departure and $\mathrm{CH}_{4}-\mathrm{O}_{2}$ propulsion thereafter, leads to the following approximate results for the ratio of IMLEO to the transferred payload mass:

- $\quad$ Mass utilized on outward leg toward Mars: 3

- $\quad$ Mass utilized on the surface of Mars: 7

- $\quad$ Mass utilized on return leg from Mars: 8

According to Table 12, the ALS estimates for the LSS masses (outbound, on the surface, and inbound) are $5 \mathrm{mT}, 22$ $\mathrm{mT}$ and $5 \mathrm{mT}$, respectively. The equivalent IMLEO values are $15 \mathrm{mT}, 154 \mathrm{mT}$, and $40 \mathrm{mT}$, respectively, for a total IMLEO of $210 \mathrm{mT}$.

\section{Indigenous Water on Mars}

As Table 12 shows, the largest single LSS mass is that required to supply water to a crew of six for up to 600 days on the surface of Mars. The ALS does not seem to have addressed the possibility of utilizing indigenous water from Mars that in principle could eliminate the need to recycle water and oxygen while on the surface. Feldman et al. (2004) have demonstrated the widespread occurrence of nearsurface water on Mars by remote sensing with a neutron spectrometer, and this observation is supported by numerous theoretical studies such as that of Schorghofer and Aharonson (2005).

\section{Summary and Conclusions}

The requirements for life support for the lengthy excursions involved in Mars missions require further study. It is likely that requirements will be more demanding than those for the limited periods involved in ISS or lunar sorties. Table $1 \mathrm{C}$ provides some rough guesses estimates of requirements for life support that can be used for purposes of early planning.

When combined with the durations involved, these levels of individual requirements lead to predictions of macro requirements for a crew of six over Mars mission segments shown in column 3 of Table 12. Table 12 also provides ALS estimates of the masses of systems to provide these requirements. However, the underlying experimental basis for the ALS estimates in Table 12 in terms of experimental data are unclear. Of particular concern is the need for fail- safe systems on missions to Mars that are not amenable to repair using orbital replacement units. As Hanford (2005) said:

"This type of analysis includes several inescapable sources of variation from actual flight systems. (1) These estimations fail to consider contingency or redundancy in any detail. (2) All calculations above use only single-string life support system architecture. (3) The preliminary nature of the data employed for the advanced equipment."

According to Table 12 the required LSS for a round trip Mars mission is about $32 \mathrm{mT}$, and as mentioned previously, this requires an initial mass in LEO of $\sim 210 \mathrm{mT}$. But this is an optimistic estimate based on the lower requirements in column 3 of Table 12. Furthermore when contingency and redundancy requirements are taken into account, this is likely to increase considerably.

Use of indigenous water on Mars may provide significant mass savings as well as great risk reduction.

It is hoped that in the future, the ALS will:

(1) Concentrate on systems with very high reliability for long durations rather than systems with very high recovery percentages. For Mars, a LSS with 90\% recovery and 99.8\% reliability would be far more valuable than one with $99.8 \%$ recovery and $90 \%$ reliability.

(2) Provide clearer delineation of data sources with particular emphasis on which data are based on experiment, and what the duration of the experiments were.

(3) Give more attention to use of the widespread near-surface water resources on Mars.

\section{Acknowledgement and Disclaimer}

A portion of the research described in this document was carried out at the Jet Propulsion Laboratory, California Institute of Technology, under a contract with the National Aeronautics and Space Administration. The conclusions reached in this document are those of the author, and do not necessarily represent the viewpoints of the Jet Propulsion Laboratory, California Institute of Technology, or the National Aeronautics and Space Administration. 
Table 8. Comparison of ALS estimated masses with Rapp estimates (this paper) of required resource masses for Mars Transit Vehicle using Baseline ECLSS Technologies.

\begin{tabular}{|c|c|c|c|c|c|}
\hline Subsystem / Interface & $\begin{array}{l}\text { Phys. Plant } \\
\text { MPP (kg) }\end{array}$ & $\begin{array}{l}\text { Maximum } \\
\text { MB }(\mathrm{kg})\end{array}$ & $\begin{array}{c}\text { Resource Need } \\
\text { MT (kg) }\end{array}$ & $\begin{array}{l}\text { Implied } \\
\text { recycle } \\
\text { efficiency }\end{array}$ & $(\mathrm{MPP}+\mathrm{MB}) / \mathrm{MT}$ \\
\hline Air & 2,190 & 1329 (b) & $6,500-8,700$ & $>80 \%(a)$ & 0.5 \\
\hline Biomass & 761 & & & & \\
\hline Food & 2,840 & & 3,200 & & \\
\hline Thermal & 329 & & & & \\
\hline Waste & 382 & & & & \\
\hline Water & 3,353 & $596(b)$ & $47,500-65,000$ & $>99 \%(a)$ & 0.08 \\
\hline $\begin{array}{c}\text { Extravehicular Activity } \\
\text { Support }\end{array}$ & 0 & & & & \\
\hline Human Accommodations & 1,763 & & & & \\
\hline Totals & 11,617 & & & & \\
\hline
\end{tabular}

(a) Cannot be exact here because data for storage includes both tankage and air or water. Calculation is based on lower value for feedstock need. (b) Assumes tankage mass is zero and all storage is air or water.

Table 9. Comparison of ALS estimated masses with Rapp estimates (this paper) of required resource masses for Mars Ascent/Descent Lander using Baseline ECLSS Technologies.

\begin{tabular}{|c|c|c|c|c|c|}
\hline Subsystem / Interface & $\begin{array}{l}\text { Phys. Plant } \\
\text { MPP (kg) }\end{array}$ & $\begin{array}{l}\text { Maximum MB } \\
(\mathrm{kg})\end{array}$ & $\begin{array}{c}\text { Resource Need } \\
\text { MT (kg) }\end{array}$ & $\begin{array}{l}\text { Implied } \\
\text { recycle } \\
\text { efficiency }\end{array}$ & $(\mathrm{MPP}+\mathrm{MB}) / \mathrm{MT}$ \\
\hline Air & 1,071 & $263(b)$ & $540-720$ & $>51 \%(a)$ & 2.4 \\
\hline Biomass & 0 & & & & \\
\hline Food & 620 & & 270 & & \\
\hline Thermal & 296 & & & & \\
\hline Waste & 69 & & & & \\
\hline Water & 737 & $91(b)$ & $4000-5400$ & $>98 \%(a)$ & 0.20 \\
\hline $\begin{array}{c}\text { Extravehicular Activity } \\
\text { Support }\end{array}$ & 22 & & & & \\
\hline Human Accommodations & 188 & & & & \\
\hline Totals & 3,001 & & & & \\
\hline
\end{tabular}

(a) Cannot be exact here because data for storage includes both tankage and air or water. Calculation is based on lower value for feedstock need. (b) Assumes tankage mass is zero and all storage is air or water.

Table 10. Comparison of ALS estimated masses with Rapp estimates (this paper) of feedstock masses for Mars Surface Habitat Lander using Baseline ECLSS Technologies.

\begin{tabular}{|c|c|c|c|c|c|}
\hline Subsystem / Interface & $\begin{array}{l}\text { System } \\
\text { Mass (kg) }\end{array}$ & $\begin{array}{c}\text { Maximum } \\
\text { MB }(\mathrm{kg})\end{array}$ & $\begin{array}{c}\text { Rapp estimate } \\
\text { of feedstock } \\
\text { need }(\mathrm{kg})\end{array}$ & $\begin{array}{l}\text { Implied } \\
\text { recycle } \\
\text { efficiency }\end{array}$ & $(\mathrm{MPP}+\mathrm{MB}) / \mathrm{MT}$ \\
\hline Air & 4,195 & 2956 (b) & $10,800-14,400$ & $>73 \%(a)$ & 0.67 \\
\hline Biomass & 898 & & & & \\
\hline Food & 7,580 & & 5400 & & \\
\hline Thermal & 382 & & & & \\
\hline Waste & 668 & & & & \\
\hline Water & 10,380 & $6243(b)$ & $79,200-108,000$ & $>92 \%(a)$ & 0.20 \\
\hline Extravehicular Activity Support & 1,292 & & & & \\
\hline Human Accommodations & 2,938 & & & & \\
\hline Totals & 28,333 & & & & \\
\hline
\end{tabular}

(a) Cannot be exact here because data for storage includes both tankage and air or water. Calculation is based on lower value for feedstock need. (b) Assumes tankage mass is zero and all storage is air or water. 
Table 11. Summary of implied recycle efficiencies and (MPP+MB)/MT mass ratios.

\begin{tabular}{|c|c|c|c|c|c|c|}
\hline & $\begin{array}{l}\text { Duration } \\
\text { (days) }\end{array}$ & Resource & Requirement $(\mathrm{kg})$ & $\begin{array}{c}\text { Maximum } \\
\text { Cache } \\
(\mathrm{kg})(\mathrm{c})\end{array}$ & $\begin{array}{l}\text { Implied } \\
\text { recycle } \\
\text { efficiency }\end{array}$ & $(\mathrm{MPP}+\mathrm{MB}) / \mathrm{MT}$ \\
\hline \multirow{2}{*}{ Mars Transit Vehicle } & \multirow{2}{*}{$360(a)$} & air & $6500-8700$ & 1329 & $>80 \%$ & 0.5 \\
\hline & & water & $47,500-65,000$ & 596 & $>99 \%$ & 0.08 \\
\hline \multirow{2}{*}{$\begin{array}{c}\text { Mars Ascent/ Descent } \\
\text { Lander }\end{array}$} & \multirow{2}{*}{$30(b)$} & air & $540-720$ & 263 & $>51 \%$ & 2.4 \\
\hline & & water & $4000-5400$ & 91 & $>98 \%$ & 0.2 \\
\hline \multirow{2}{*}{ Mars Surface Habitat } & \multirow{2}{*}{600} & air & $10,800-14,400$ & 2956 & $>73 \%$ & 0.67 \\
\hline & & water & $79,200-108,000$ & 6243 & $>92 \%$ & 0.2 \\
\hline
\end{tabular}

(a) No account seems to have been taken of the need to store the system for a significant period between two 180-day transits. (b) 30 seems like "over-kill" here. (c) Neglects tankage mass. Assumes Hanford (2005) stated storage mass is $100 \%$ resource.

Table 12. Crude Estimates for Preliminary Planning Purposes. Cells marked $*$ have masses included in the habitat, not the LSS.

\begin{tabular}{|c|c|c|c|c|c|}
\hline & Resource & Requirement $(\mathrm{kg})$ & $\begin{array}{c}\text { Physical Plant } \\
(\mathrm{kg})\end{array}$ & $\begin{array}{c}\text { Back-up Cache } \\
(\mathrm{kg})\end{array}$ & $\begin{array}{c}\text { Total ECLSS } \\
\text { Mass }(\mathrm{kg})\end{array}$ \\
\hline \multirow{5}{*}{$\begin{array}{l}\text { Mars Transit } \\
\text { Vehicle } \\
\text { (360 days) }\end{array}$} & Air & $6500-8700$ & 870 & 1350 & 2220 \\
\hline & Water & $47,500-65,000$ & 2770 & 600 & 3370 \\
\hline & Food & 3240 & $*$ & 3240 & 3240 \\
\hline & Waste Disposal Mtls & 1100 & $*$ & 1100 & 1100 \\
\hline & Total & & & & 9930 \\
\hline \multirow{5}{*}{$\begin{array}{c}\text { Mars Ascent/ } \\
\text { Descent Lander } \\
\text { (30 days) }\end{array}$} & Air & $540-720$ & 800 & 270 & 1070 \\
\hline & Water & $4000-5400$ & 650 & 90 & 740 \\
\hline & Food & 270 & $*$ & 270 & 270 \\
\hline & Waste Disposal Mtls & 90 & $*$ & 90 & 90 \\
\hline & Total & & & & 2170 \\
\hline \multirow{5}{*}{$\begin{array}{c}\text { Mars Surface } \\
\text { Habitat } \\
\text { (600 days) }\end{array}$} & Air & $10,800-14,400$ & 1270 & 2930 & 4220 \\
\hline & Water & $79,200-108,000$ & 4140 & 6250 & 10390 \\
\hline & Food & 5400 & $*$ & 5400 & 5400 \\
\hline & Waste Disposal Mtls & 1800 & $*$ & 1800 & 1800 \\
\hline & Total & & & & 21810 \\
\hline
\end{tabular}

\section{Acronyms List}

ALS Advanced life support system

BVAD Baseline values and assumptions document

CM Crew member

CT Crew time

DRM Design reference mission

ECLSS Environmental control and life support system

ESM Equivalent system mass

ILSSTF Integrated Life Support Systems Test Facility

IMLEO Initial mass in low Earth orbit

ISRU In situ resource utilization

ISS International Space Station

IWRS Integrated water recovery system

JSC NASA Johnson Space Center

LEO Low Earth orbit

LMLSTP Lunar-Mars Life Support Test Project

LSS Life support system

MB Mass of back-up cache

MLS Mass of LSS
MPP Mass of physical plant

MT Mass of total resources needed

ORU Orbital replacement unit

P/C Physico-chemical

RP Recovery percentage

SIMA System integration, modeling and analysis

SWIS Solid waste incineration system

TBD To be determined

TRL Technology readiness level

VPCAR Vapor phase catalytic ammonia removal system

VPGC Variable pressure growth chamber

WRS Water Recovery system

\section{Supporting Data}

root directory

rapp_mars_2006_0005.pdf this file

Anderson2004.pdf JSC IWRS report (2004)

Anonymous2002.pdf JSC ALS Project Plan (2002)

Anonymous2005.pdf NASA ESAS report (2005) 
Drake1998.pdf JSC DRM-3 report (1998)

Graf2002.pdf Life support system guidelines (2002)

Hanford2004A.pdf NASA ALS Research \& Development Metric (2004)

Hanford2004B.pdf JSC ALS Baseline Values \& Assumptions (2004)

Hanford2004C.pdf NASA ALS Research \& Development Metric (2004)

Hanford2005.pdf ALS Research \& Development Metric (2005)

HoffmanKaplan1997.pdf JSC DRM-1 report (1997)

Lange2003.pdf JSC ALS Requirements (2003)

SandersDuke2005.pdf NASA ISRU Capability Roadmap (2005)

Stafford2001.pdf JSC ALS Systems Integration, Modeling \& Analysis (2001)

\section{References}

Anderson, M. S. (2004) "Summary of Water Processing Trade Studies and Analysis of J SC I ntegrated Water Recovery System (IWRS)" CTSD-ADV-543, JSC 62185. Anderson2004.pdf

Anonymous (2002) "Advanced Life Support Project Plan" CTSD-ADV-348 Rev C, JSC 39168. Anonymous2002.pdf

Anonymous (2005) The NASA Exploration Systems Architecture Study (ESAS) Final Report. Anonymous2005.pdf

Drake, B. G. (1998) DRM-3: "NASA/SP-6107-ADD, Reference Mission Version 3.0, Addendum to the Human Exploration of, Mars: The Reference Mission of the NASA, Mars Exploration Study Team," Lyndon B. Johnson Space Center, Houston. Drake1998.pdf

Feldman, W. C., T. H. Prettyman, S. Maurice, J. J. Plaut, D. L. Bish, D. T. Vaniman, M. T. Mellon, A. E. Metzger, S. W. Squyres, S. Karunatillake, W. V. Boynton, R. C. Elphic, H. O. Funsten, D. J. Lawrence, and R. L. Tokar (2004) "Global distribution of near-surface hydrogen on Mars," J ournal of Geophysical Research, 109, E09006. doi: 10.1029/2003JE002160

Graf, J., B. Finger and K. Daues (2002) "Life Support Systems for the Space Environment: Basic Tenets for Designers, Rev. A" Informal NASA J SC Report. Graf2002.pdf

Hanford, A. J. (2004A) "Advanced Life Support Research and Technology Development Metric - Fiscal Year 2004" NASA/CR-2004-208944 Lockheed Martin Space Operations, Houston 77058. Hanford2004A.pdf

Hanford, A. J. (2004B) "Advanced Life Support Baseline Values and Assumptions Document, Doc. Number CTSD-ADV-484 A, NASA CR-2004-208941, JSC 47804 Lockheed Martin Space Operations. (Update to previous version CTSD-ADV-484, 08 May 2002). Hanford2004B.pdf

Hanford, A. J. (2004C) "Subsystem Details for the Fiscal Year 2004 Advanced Life Support Research and Technology Development Metric" MSAD-04-0306. Hanford2004C.pdf

Hanford, A. J. (2005) "Advanced Life Support Research and Technology Development Metric - Fiscal Year 2005" ESCG-4470-05-TEAN-DOC-0157, Lockheed Martin Space Operations, Houston, 77058. Hanford2005.pdf

Hoffman, S. J. and D. I. Kaplan (1997) DRM-1: "Human Exploration of Mars: The Reference Mission of the NASA Mars Exploration Study Team," Lyndon B. Johnson Space Center, Houston, Texas, NASA
Special Publication 6107. HoffmanKaplan1997.pdf

Lange, K. E., C. H. Lin, B. E. Duffield, and A. J. Hanford (2003) "Advanced Life Support Requirements Document," J SC-38571C, CTSD-ADV-245C. Lange2003.pdf

Sanders, J. and M. Duke (2005) "ISRU Capability Roadmap Team Final Report" Informal report edited by J. Sanders (JSC) and M. Duke (Colorado School of Mines). SandersDuke2005.pdf

Schorghofer, N. and O. Aharonson (2005) "Stability and exchange of subsurface ice on Mars" J ournal of Geophysical Research, 110, E05003. doi: 10.1029/2004JE002350

Stafford, K. W., A. E. Drysdale, J. A. Levri, A. J. Hanford and M. K. Ewert (2001) "Advanced Life Support Systems Integration, Modeling, and Analysis Reference Missions Document," J SC-39502, CTSD-ADV-383. Stafford2001.pdf 